\title{
Polidocanol sclerotherapy for intraoral hemangioma of buccal mucosa: a rare case report
}

\section{Bukkal mukozanın intraoral hemanjiyomunda polidokanol skleroterapi: Nadir bir olgu sunumu}

\author{
Venkatesh Balaji Hange ${ }^{1}$ \\ ${ }^{1}$ Dept. of Oral and Maxillofacial Surgery, K.D. Dental College and Hospital, Mathura, Uttar Pradesh, India
}

\begin{abstract}
The term hemangioma derives from the Greek word, "hema" which expresses blood, "angio" implies vessel, "oma" corresponds to tumor. A hemangioma is a type of an innocuous lesion of blood vessels or vascular components defined by a proliferative growth stage and a very prolonged involutive stage. The prevalence of hemangiomas is estimated to be around $2-3 \%$ in neonates, $10-12 \%$ in the first year of life, and $22-30 \%$ found amongst babies whose weight is less than $1000 \mathrm{~g}$ at the time of birth. Most of the hemangiomas occur as single lesion. Peripheral hemangiomas treated by surgical excision is an example of gold standard treatment for hemangiomas. Alternatively sclerosing solutions may be used as they obliterate blood vessels, thereby leading to fibrosis and disappearance of the hemangioma. It is relatively uncommon in the oral cavity. Polidocanol (aethoxysklerol) is a detergent solution which act by causing localized inflammatory reaction.
\end{abstract}

Key words: sclerotherapy, hemangioma, polidocanol, vascular malformations, buccal mucosa

\section{O̊zet}

Hemanjiyom terimi, Yunanca kanı ifade eden "hema" kelimesinden türemiştir, "angio" damar anlamına gelirken "oma" tümöre karşılık gelir. Hemanjiyom, kan damarlarının veya damar bileşenlerinin proliferatif büyüme aşaması ve çok uzun bir çekilme, gerileme döneminden oluşur. Hemanjiyom prevalansının yenidoğanlarda \%2-3, yaşamın ilk yılında \%10-12 ve doğum ağırlığı 1000 gramdan az olan yenidoğanlarda \%22-30 olarak tahmin edilmektedir. Hemanjiyomların çoğu tek lezyon olarak ortaya çıkar. Cerrahi eksizyonla tedavi edilen periferik hemanjiyomlar, hemanjiyomlar için altın standart tedavinin bir örneğidir. Alternatif olarak sklerozan çözeltiler, kan damarlarını yok ettikleri için kullanılabilirler, böylece fibrozise ve hemanjiyomun kaybolmasına neden olurlar. Hemanjiomlar ağız boşluğunda nispeten nadirdir. Polidokanol (aethoxysklerol), lokalize inflamatuar reaksiyona neden olarak etki eden bir deterjan solüsyonudur.

Anahtar kelimeler: skleroterapi, hemanjiyom, polidokanol, vasküler malformasyonlar, bukkal mukoza

Corresponding author: Dr.Venkatesh Balaji Hange, Jatal Heritage, Flat no:75, near RTO office, Latur-413512, Maharshtra, India Phone: +917385051925, E-mail: venkateshhange@gmail.com

Received: 18 July 2020 Accepted: 12 December 2020

Conflicts of Interest: None

Funding: None

How to cite this article: Hange VB. Polidocanol sclerotherapy for intraoral hemangioma of buccal mucosa: a rare case report. Mucosa 2020;3:104-109

(c) (1) (5) This work is licensed under a Creative Commons Attribution-NonCommercial 4.0 International License. 


\section{Introduction}

Vascular anomalies are either categorized as hemangiomas or vascular defects. The term hemangioma derives from the Greek word, "hema" which expresses blood, "angio" implies vessel, "oma" corresponds to tumor. ${ }^{1}$ The first description dates back to 1897 , Poncet and Dor mentioned this as human Botryomycose. In 1973, Sznejder et al. had originally coined the term hemangioma and entitled as "hemaorragic hemangioma." 2

A hemangioma is a type of an innocuous lesion of blood vessels or vascular components defined by a proliferative growth stage and a very prolonged involutive stage. They are usually classified as capillary, cavernous, or mixed hemangiomas. Oral mucosa and skin are affected mostly, followed by bone and muscles. Inside the oral cavity, hemangiomas often seem as flat or raised deep blue swelling over the exterior of the mucosa. ${ }^{3}$ Hemangiomas are not usually seen at birth. A majority of hemangiomas appear during the first six weeks of life. These tumors are most prevalent in females, with a 3:1 ratio (F:M). This tumor is also more frequent in Caucasian race. The most common site is the head and neck region $(60 \%)$, followed by the trunk (25\%), and then the limbs (15\%). Cutaneous hemangiomas are superficial (capillary) in approximately $60 \%$ of cases and deep (cavernous) in $15 \%$ of cases. ${ }^{4}$

In 1982, Mulliken and Glowacki described a classification system for vascular tumors including two broad headings of hemangioma and vascular malformation. Hemangiomas are subcategorized again on the account of their histological presentation as capillary, cavernous and mixed lesions and recently a sclerosing variety that tends to undergo spontaneous fibrosis has been discovered. ${ }^{5}$ Intramuscular hemangiomas (IMH) are rather unusual lesions. This represents less than $1 \%$ of all hemangioma, and is typically found in the skeletal muscles of trunk or limbs. IMH most commonly occurs in the pelvic region, but in some instances it can also occur in head and neck regions (10\% to 15\%), generally in the masseter, sternomastoid, and trapezius muscles. The masseter muscle is the most common- ly involved, constituting near about $36 \%$ of all head and neck IMH cases. ${ }^{6}$ The prevalence of hemangiomas is estimated to be around $2-3 \%$ in neonates, $10-12 \%$ below 1 year of age, and $22-30 \%$ found amongst babies whose weight is less than $1000 \mathrm{~g}$ at the time of the birth. Most of the hemangiomas occur as single lesion, while multiple tumors are found in $20 \%$ of affected patients. ${ }^{7}$

The standard radiographs are common diagnostic tools for detection of hemangioma. Standard radiographs can detect phleboliths, which are strongly suggestive of hemangioma. In addition to this, diagnostic imaging modalities such as computed tomography (CT), magnetic resonance imaging (MRI), and ultrasound are effective tools in diagnosis of hemangioma even before the actual operative procedure. Out of these, MRI is considered the highly reliable imaging technique for tissue characterization and identification of the extent of hemangioma. Whereas definite diagnosis of vascular malformations or suspected hemangioma may be done using digital compression and diascopy. ${ }^{8,9}$

Smaller circumscribed lesions or peripheral hemangiomas treated by surgical excision is an example of one of the gold standard treatment for hemangiomas. Surgical excision of hemangiomas in the oral cavity and lips can be extremely invasive and cause bleeding that is difficult to control. Alternatively sclerosing solutions may be used for the management of these vascular tumors, they obliterate blood vessels, thereby leading to fibrosis and disappearance of the hemangioma. ${ }^{9,10}$

\section{Case report}

A 50-year-old male patient was referred to our department. The chief complaints included cheek bite on the buccal mucosa on the right cheek for 7-8 months.Patient developed swelling due chronic cheek bite. Initially swelling was small in size and gradually enlarged in size to attain the present size (Fig. 1) without inducing any pain according to history. Intraoral physical examination described, a sessile growth on the right buccal mucosa almost near to the opening of the Stensen's duct (Fig. 3) which is an opening of secretions 


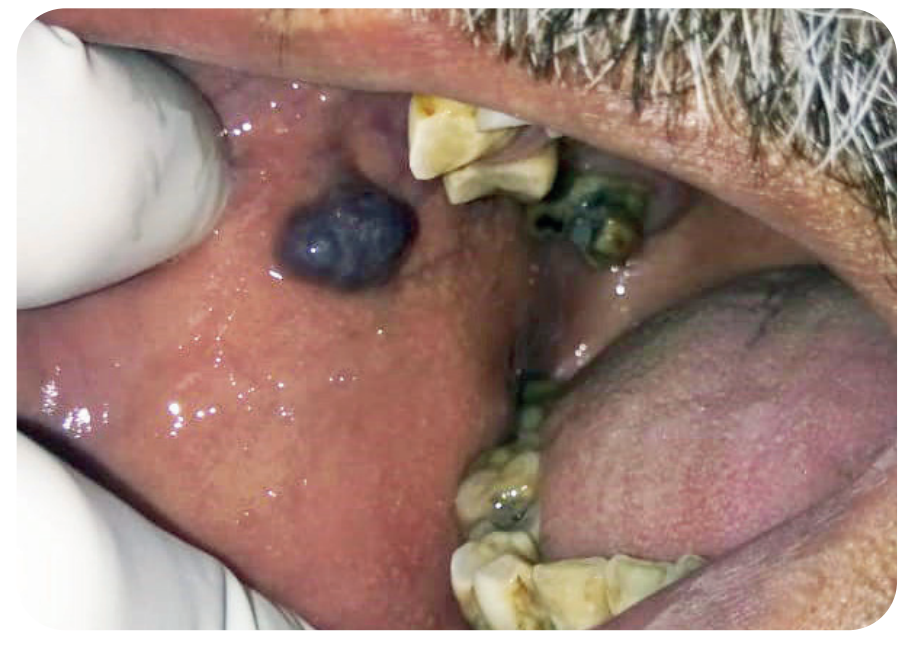

Fig. 1. Intraoral hemangioma on right buccal mucosa

from parotid gland. Smooth, irregular painless swelling measuring about $1.5 \times 2.5 \mathrm{~cm}$, dark blue colored lesion under intact mucosa was found on right side of buccal mucosa which appears to be soft on palpation. Upon firm palpation over the swelling color changed and became flat which later upon removal of pressure came back to its pathognomic color. This was highly suspicious of vascular malformations, hence patient was advised for Doppler USG to reveal the vascular status of the lesion. At the same time, patient was referred for routine investigations.

The differential diagnosis of hemangioma or vascular malformation or lymphangioma was made on the basis of case history, intraoral examinations. Final diagnosis was made on the basis of Doppler USG (Fig. 2), which showed a vascular lesion with an arterial as well as a venous supply to the lesion.

Treatment procedures for heamangioma of oral cavity may be highly invasive and cause bleeding. Treatment protocol for the management of hemangioma includes intralesional injection of sclerosing agent under local anaesthesia which is a non-invasive alternative treatment to surgical excision.

Stensen's duct was cannulate, purse-string suture were given. Local infiltration was given using $2 \%$ lignocaine solution prior injecting sclerosing agent (Fig. 4) around the lesion, 2\% polidocanol solution
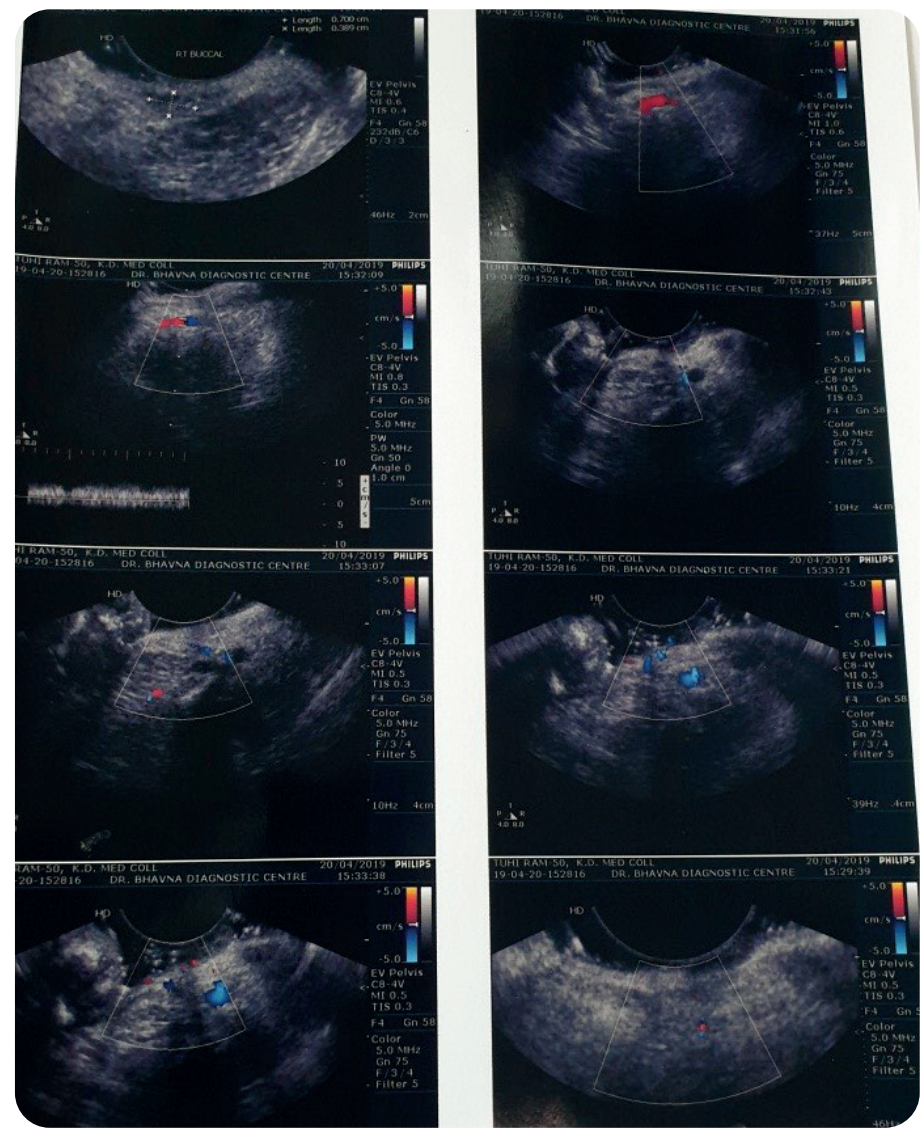

Fig. 2. Doppler USG of right buccal mucosa shows feeder vessels both arteries and vein supplying into the lesion

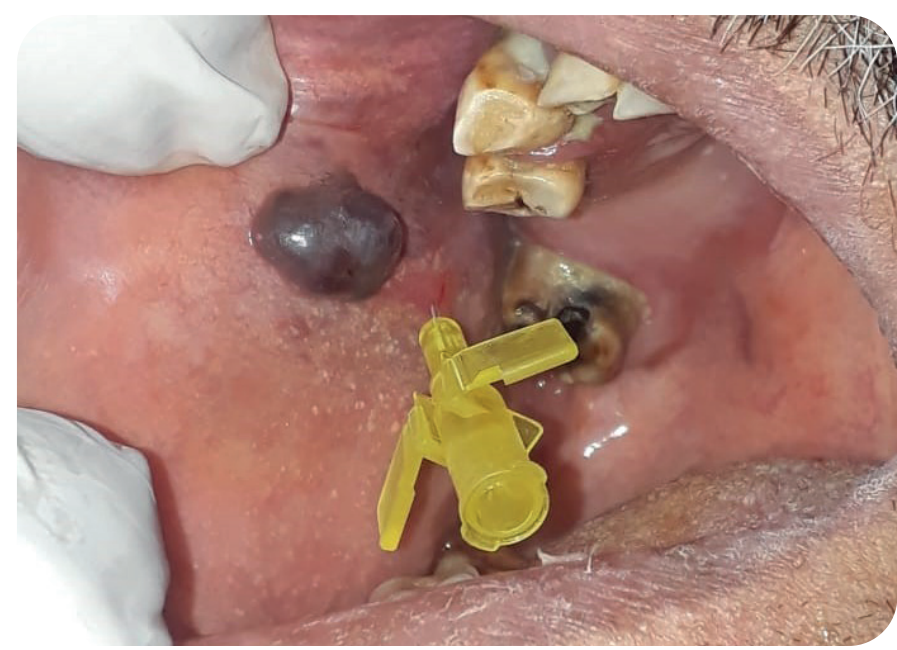

Fig. 3. Cannulation of Stenson's duct which lies in proximity with the lesion 
was injected slowly into the periphery of the lesion (Fig. 5) between the sutures. $0.4 \mathrm{ml}$ of the solution was injected. The patient was put on antibiotic and analgesic therapy for five days. During follow up, size of lesion decreased but not completely resolved hence the procedure was repeated after two weeks (Fig. 6). One week after the $2^{\text {nd }}$ dose of sclerosing agent was given, necrosis of mucosa with pus discharge was seen, which was managed by intravenous administration of amoxycillin-clavulanic acid, metronidazole for twice a day for five days. The lesion was tremendously reduced in subsequent follow-ups and mucosalization was seen over a time period of 1 month.

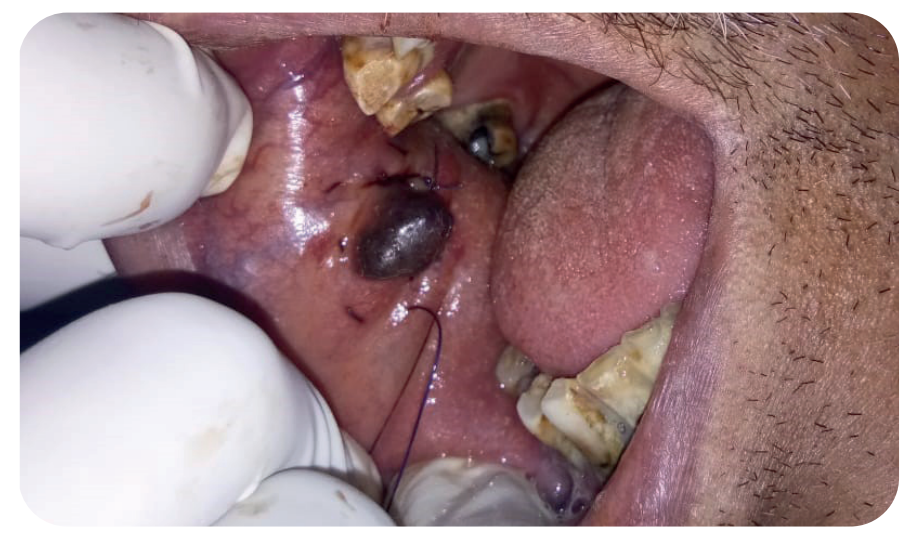

Fig. 4. Localization of hemangioma using purse-string suture given around the lesion

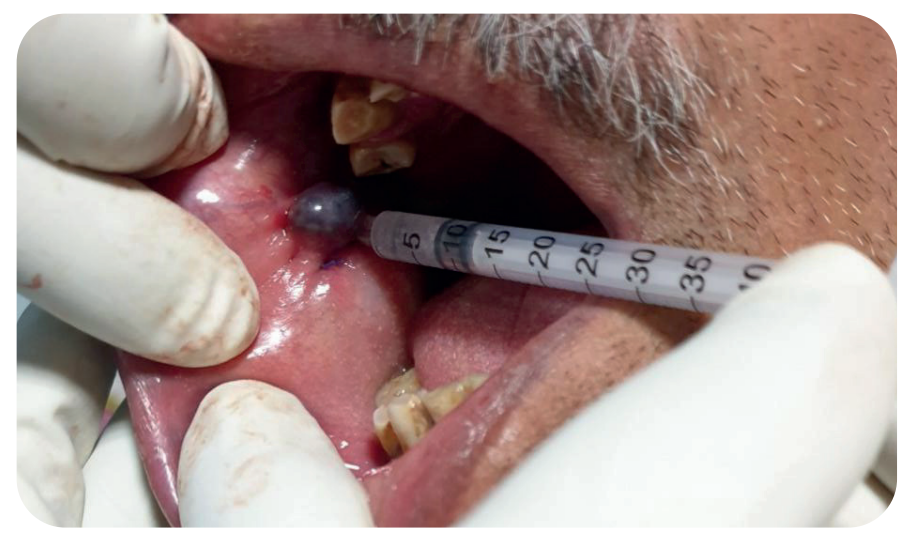

Fig. 5. Application of $2 \%$ polidocanol solution slowly into the periphery of the lesion between the sutures

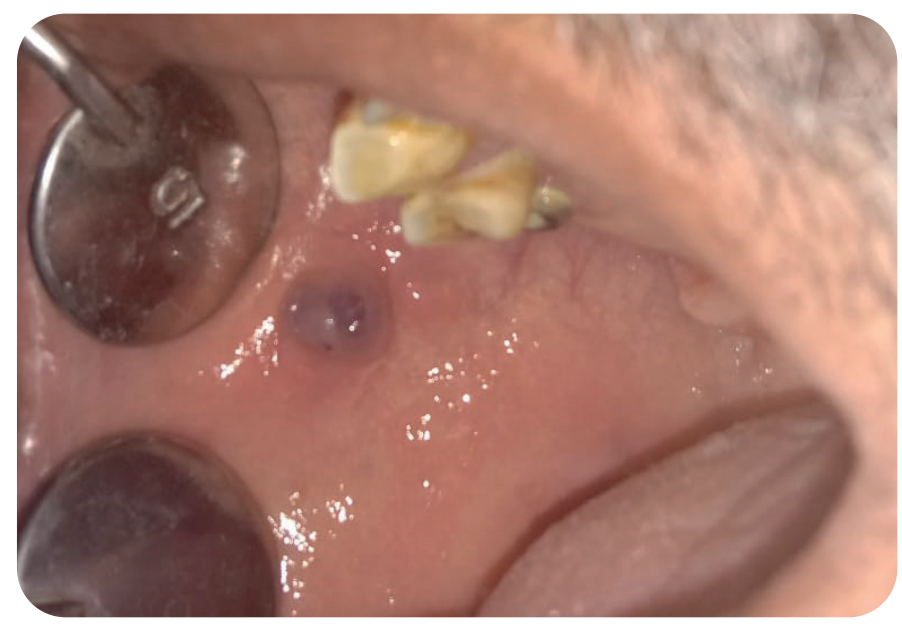

Fig. 6. Reduction in the volume of the lesion is seen two weeks later

\section{Discussion}

Hemangiomas are presumed as benign tumors of the infancy and childhood, and have a varying life cycle, recognized by three stages: endothelial cell proliferation, rapid growth, and, at finally, spontaneous involution. The prevalence of hemangiomas is approximately $2-3 \%$ in neonates, $10-12 \%$ below 1 year of age and 22 $30 \%$ found among st babies who are under $1000 \mathrm{~g}$ of weight at the time of birth. It thrice more commonly involves in females than the males. ${ }^{11,12}$ Hemangioma is regarded to be among the soft tissue masses of the head and neck, which is relatively uncommon in the oral cavity. ${ }^{5}$

Studies have acknowledged that oral site is less commonly involved by hemangioma, but if involved it is commonly seen on gingiva, followed by lip, tongue and palate. ${ }^{13}$ However Akyol et al. proposed prevalent intraoral hemangioma locations as buccal mucosa (45.2\% ), followed by tongue (35.5\%), lip (9.7\%), gingiva $(6.5 \%)$ and palate $(3.2 \%)$, respectively. ${ }^{1,14}$ Regarding age, sex and location, our case was an unusual presentation of hemangioma. The exact cause and development of the hemangiomas has not yet been discovered. Different hypothesis were presented for the etiopathogenesis of hemangioma by various authors. The two most recommended hypothesis are hemangioma developing from disrupted placental tissue and 
disordered stimulation of angiogenesis. ${ }^{12}$

As hemangioma is composed of endothelial cells, these cells are originated from disrupted placental tissue which are embedded in the foetal soft tissues during the time of gestation or birth. This is based on fact that markers of hemangioma have been found in placental tissue. The breakthrough of endothelial progenitor and stem cells in patients' bloodstream with the hemangioma gave rise to the new hypothesis. Then, the progress of hemangioma in animal experiments the stem cells removed from human specimens supported this theory. ${ }^{15}$ Whereas another theory states that excesses of these angiogenic factors causes disordered angiogenesis, to an extent that excessive angiogenic factors outweigh gamma-interferon, tumor necrosis factor-beta, transforming growth factor-beta which are key angiogenesis inhibitors.

Those angiogenic factors are cytokines such as basic fibroblast endothelial growth factor (bFGF) and vascular growth factor (VEGF). ${ }^{2}$ Sclerosing agents are essentially annoyances which damage the endothelial surfaces and eventually lead to the erosion of the space between such surfaces. Sclerosing agents are categorized into three separate categories depending on the mode of action which causes the endothelium damage.

a. Detergents: sodium morrhuate, sodium psylliate, sodium tetradecyl sulfate, ethanolamine oleate, and polidocanol, i.e. aethoxysklerol. The detergents cause injury by altering the surface tension surrounding endothelial cells.

b. Osmotics: saline or dextrose solution in hyper-tonic state. Their mode of action is through endothelial damage through dehydration.

c. Chemical irritants: They include the corrosives, which act by a cauterizing action and those which injure cells by a heavy metal effect. These are chromated glycerin, poly-iodinated iodide. ${ }^{3,9}$

One of the alternative treatment available for oral hemangioma is laser therapy mainly relied on the coagulative effect of superpulsed laser beams causing painless vaporization of tissue in real time. Lasers are mainly used for superficial / ulcerated hemangioma because the depth of penetration of laser into of PDL(periodontal ligament) is approximately $1.2 \mathrm{~mm}$. Complications associated with laser use comprise of ulceration, pain, residual scarring components of hemangiomas, and sometimes a life-threatening bleeding. ${ }^{16}$

Polidocanol (aethoxysklerol) is a detergent solution that acts by causing a localized inflammatory reaction in the hemangiomatous space, initiated through obliteration by thrombosis, resulting in fibrosis of the endothelial cavities resulting in regression of the lesion. These advantages of sclerotherapy are the minimal or absence of pain during procedure, superior efficiency as well as safety, and rare allergic reactions. As there is no direct hemolysis by the use of drug, hyperpigmentation is less likely to occur. ${ }^{3,17}$ Complications include necrosis of the adjacent tissue, abscess formation, soft tissue loss, etc. Sclerotherapy can cause necrosis of the adjacent tissue by virtue of high concentration of sclerosing solution. Necrosis creates environment suitable for bacterial growth which leads to abscess formation.

Other alternative treatment options include laser therapy, Steroid injection therapy, interferon-alfa injections or cryotheraphy.

Minkow et al. stated that the interval of two weeks between injections allows the surrounding tissues to recover from the vascular damage and reduces the inflammatory reactions. ${ }^{10}$ In our case the size of lesion decreased in $1^{\text {st }}$ injection but it was not completely resolved hence the procedure was repeated two weeks later in accordance with literature.

\section{Conclusion}

Intraoral hemangioma of buccal mucosa is an uncommon presentation. Although majority of hemangioma resolves on itself, few cases which does not undergo involution require treatment. Antecedent detection, biopsy and definitive treatment can efficiently avoid future complications. Decision of treatment choice should consider challenges such as close proximity with neurovascular structures. Surgical excision is gold standard for management of hemangioma but has 
complications related to its invasive nature of treatment. Sclerotherapy is a well established, efficient, cost effective, and simple maneuver to cure hemangioma, thus sclerotherapy emerges as conservative alternative to current gold standard management.

\section{References}

1. Akyol MU, Yalciner EG, Doan AI. Pyogenic granuloma (lobular capillary hemangioma) of the tongue. Int J Pediatr Otorhinolaryngol 2001;58:239-41.

2. Abidullah M, Hussain J, Karpe T, Gaddikeri K. Cavernous hemangioma of buccal mucosa: a rare case report with a reappraisal of differential diagnosis \& review of literature. BBB 2014;4:638-43.

3. Trivedi K, Soni A, Meshack R, Kulthya RS. Intraoral hemangioma: An overview of the clinical entity. J Int Clin Dent Res Organ 2015;7:79-81.

4. Sangma R, Patar M. Role of polidocanol as sclerosant in treatment of hemangiomas of head and neck region. BJOHNS 2017;25:148-54.

5. Abdullah JM, Arf AN, Mohammed KK. Hemangioma of the buccal mucosa: a case report and review of the literature. Sch J Dent Sci 2016;3:228-30.

6. Park JW, Kim $\mathrm{CH}$, Moon CW. Intramuscular hemangioma in buccal cheek: a case report. J Korean Assoc Oral Maxillofac Surg 2017;43:262-6.

7. Kamala KA, Ashok L, Sujatha GP. Cavernous hemangioma of the tongue: a rare case report, Contemp Clin Dent 2014;5:95-8.

8. Yonetsu K, Nakayama E, Yuasa K, Kanda S, Ozeki $\mathrm{S}$, Shinohara M. Imaging findings of some buccomasseteric masses. Oral Surg Oral Med Oral Pathol Oral Radiol Endod 1998;86:755-9.

9. Abdyli RA, Abdyli YLL, Perjuci F, et al. Sclerotherapy of intraoral superficial hemangioma. Case Reports in Dentistry 2016;4320102:1-5.

10. Minkow B, Laufer D, Gutman D. Treatment of oral hemangiomas with local sclerosing agents. Int J Oral Surg 1979;8:18-21.

11. Hashmi S, Idrees F. Massive hemangioma of buccal mucosa in adults: a case report. EC Dental Science 2017;15:9-14.

12. Rathod V, Verma C, Sharma S, Mala S. Hemangioma of left buccal mucosa: A case report. Arch of Dent and Med Res 2016;2:61-5.

13. Kocer U, Ozdemir R, Tiftikcioglu YO, Karaaslan O. Soft tissue hemangiomas, formation within a previously excised intraosseous hemangioma site. $\mathrm{J}$ Craniofac Surg 2004;15:82-3.

14. Acikgoz A, Sakallioglu U, Ozdamar S. Uysal A. Rare benign tumors of oral cavitycapillary heman- giomas of palatal mucosa: a case report. Int J Paediatr Dent 2000;10:161-5.

15. Pattar P, Deore S, Patil A, Pawar S, Shinde S. Non-involuting hemangioma with perivascular fibrosis: an uncommon presentation. J Evidence Based Med \& Healthcare 2015;2:8523-6.

16. Wittman PM, Wagner AM, Scherer K, Waner M, Frieden IJ.Complications following pulsed dye laser treatment of superficial hemangiomas. Lasers Surg Med 2006;38:116-23.

17. Weiss RA, Feied CF, Weiss MA. Vein diagnosis and treatment. (Eds). McGraw-Hill, New York, USA, 2001 . 